\title{
Primer registro del género Carminodoris Bergh, 1889 (Gastropoda: Opisthobranchia: Nudibranchia: Doridoidea: Discodorididae) en el Caribe colombiano
}

\section{First record of the genus Carminodoris Bergh, 1889 \\ (Gastropoda: Opisthobranchia: Nudibranchia: Doridoidea: Discodorididae) in the Colombian Caribbean}

\author{
Camilo Zárate ${ }^{1}$, Shanly Coneo-Gómez ${ }^{2}$ y Mónica Puyana ${ }^{3}$ \\ $\begin{array}{lll}\text { (iD) } 0000-0002-1703-4624 & \text { (D) } 0000-0002-0852-9000 & \text { (D) } 0000-0001-7600-3118\end{array}$ \\ 1 Centro de Investigación, Educación y Recreación-CEINER, Cartagena, Colombia z.juancamilo@yahoo.edu.co. \\ 2 Universidad Jorge Tadeo Lozano, Sede Santa Marta, El Rodadero, Santa Marta, Colombia. shanlyc.coneog@utadeo.edu.co. \\ 3 Universidad Jorge Tadeo Lozano, Facultad de Ciencias Naturales e Ingeniería, Departamento de Ciencias Biológicas y Ambientales, Bogotá, Colombia. \\ monica.puyana@utadeo.edu.co.
}

\section{RESUMEN}

$\mathrm{E}$ n el océano Atlántico existen solo dos registros de especies de nudibranquios pertenecientes al género Carminodoris Bergh, 1889 (Discodorididae). En el presente trabajo se describe e ilustra el primer registro del género para el Caribe colombiano, a partir de un ejemplar recolectado en la isla San Martín de Pajarales, islas del Rosario, Cartagena, Colombia. Los atributos morfológicos y anatómicos del ejemplar estudiado se compararon con aquellos de las dos especies registradas para el Atlántico (Carminodoris hansrosaorum y C. madibenthos), y aquellas citadas para el Pacífico (C. nodulosa, C. grandiflora, C. bramale, C. flammea, C. bifurcata, C. armata y C. estrelyado). El ejemplar estudiado difiere de las otras especies descritas por su tamaño $(74 \mathrm{~mm})$, patrones morfológicos distintivos (pie, rinóforos, tubérculos, penacho branquial, manto, mandíbula) y fórmula radular. Este es el primer registro del género para el Caribe suroccidental y podría tratarse de una nueva especie, lo cual tendría que corroborarse con mayores estudios anatómicos y moleculares.

PALABRAS CLAVE: Nudibranquios, Discodorididae, Carminodoris, Islas del Rosario, Caribe.

\section{ABSTRACT}

I

$\mathrm{n}$ the Atlantic Ocean there are only two records of Nudibranchs belonging to the genus Carminodoris Bergh, 1889 (Discodorididae) This work describes and illustrates the first record of a Nudibranchs belonging to this genus in the Colombian Caribbean, in a sample collected on Isla San Martín de Pajarales, islas del Rosario, Cartagena, Colombia. The morphological and anatomical attributes of the studied specimen were compared with those reported for the Atlantic (Carminodoris hansrosaorum and C. madibenthos), and for the Pacific (C. nodulosa, C. grandiflora, C. bramale, C. flammea, C. bifurcata, C. armata and C. estrelyado). The studied sample differs from the other species by its size $(74 \mathrm{~mm})$, and distinctive morphological patterns (foot, tubercles, branchial plume, mantle, jaw and radular formula). This is the first report of this genus in the southwestern Caribbean and it might be a new species, yet to be confirmed, with additional anatomical and molecular studies.

KEY WORDS: Nudibranch, Discodorididae, Carminodoris, Rosario Islands, Caribbean, Colombia.

DOI: 10.25268/bimc.invemar.2019.48.2.765. 


\section{INTRODUCCIÓN}

Los nudibranquios (Mollusca: Gastropoda: Opisthobranchia) son moluscos que cuentan con una gran variedad de formas e incluyen organismos con o sin concha (Gosliner, 1994). En Colombia se encuentran registradas únicamente ocho especies de nudibranquios pertenecientes a la familia Discodorididae, dos especies al género Discodoris, un representante para los géneros Peltodoris, Diaulula, Taringa, Thordisa y uno al género Joruna que aún se encuentra por confirmar (Ardila et al., 2007). Por otra parte, el género Carminodoris (anteriormente conocido como Hoplodoris Bergh, 1880) también pertenece a esta familia (Cervera et al., 2004; Dayrat, 2010), en donde se reconocían hasta 2016 quince especies y una cuyo estatus se encuentra en duda (WoRMS Editorial Board, 2019).

La descripción de los géneros Hoplodoris y Carminodoris ha sido calificada como problemática por diferentes autores (Miller, 1991; Gosliner y Berhens, 1998; IZCN), y la falta de claridad en las descripciones se traduce en cambios constantes en los estatus taxonómicos. Fahey y Gosliner (2003) concuerdan en que la confusión de los géneros radica en la poca información de las descripciones originales propuestas por Bergh (1880 y 1889), tales como caracteres morfológicos externos y patrones de coloración de los organismos vivos. Además de esto, la falta de ejemplares y de algunos detalles del sistema reproductivo femenino en el caso de Carminodoris y órganos almacenadores de esperma en el caso de Hoplodoris, corroboran la ausencia de información para ambos géneros. A pesar de esto, el género Hoplodoris no es aceptado y actualmente todas sus especies fueron transferidas al género Carminodoris, a excepción de una que cambio al género Asteronotus (Dayrat, 2010; WoRMS Editorial Board, 2019).

Carminodoris se caracteriza por poseer el dorso del manto cubierto por tubérculos simples, largos y redondeados, la cabeza cuenta dos tentáculos orales cónicos, rádula compuesta por dientes simples y presenta hermafroditismo con un sistema reproductivo aplanado y dos regiones bien diferenciadas (Valdés, 2002). Domínguez et al. (2006) describieron una nueva especie (C. hansrosaorum) a partir de un ejemplar de $27 \mathrm{~mm}$ recolectado en la isla Cabo Frío, Río de Janeiro, Brasil, constituyéndose como el primer registro del género para el océano Atlántico. La especie fue descrita con base en la morfología, anatomía de los órganos internos y aspectos de la rádula. Posteriormente, Ortea (2016) describió una segunda especie de este género

\section{INTRODUCTION}

Nudibranchs (Mollusca: Gastropoda: Opisthobranchia) are mollusks with a variety of shapes and include organisms with or without shells (Gosliner, 1994). In Colombia, only eight nudibranchs species have been recorded that belong to the Discodoridae family, two species to the Discodoris genus, one representative for the Peltodoris, Diaulula, Taringa, Thordisa and one for the Joruna genus that has yet to be confirmed (Ardila et al., 2007). The genus Carminodoris (formerly known as Hoplodoris Bergh, 1880) also belongs to this family (Cervera et al., 2004; Dayrat, 2010), where fifteen species were recognized up until 2016 and one whose status has not yet been confirmed (WoRMS Editorial Board, 2019).

The description of the genera Hoplodoris and Carminodoris has been qualified as problematic by different authors (Miller, 1991; Gosliner and Behrens, 1998; IZCN), and the lack of clarity in the descriptions means that their taxonomic status changes constantly. Fahey and Gosliner (2003) agree that the confusion is due to the little information in the original descriptions proposed by Bergh (1880 and 1889), such as external morphological characters and coloring patterns of living organisms. In addition to this, the lack of specimens and some details of the female reproductive system in the case of Carminodoris and sperm storage organs in the case of Hoplodoris, corroborate the absence of information for both genera. Despite this, the genus Hoplodoris is not accepted and currently all its species have been transferred to the genus Carminodoris, with the exception of one that changed to the genus Asteronotus (Dayrat, 2010; WoRMS Editorial Board, 2019).

Carminodoris is characterized by simple, long and rounded tubercles on the back surface of the mantle, a head with two conical oral tentacles, radula composed of simple teeth and hermaphroditism with a flat reproductive system and two well differentiated regions (Valdés, 2002). Domínguez et al. (2006) described a new species $(C$. hansrosaorum) from a $27 \mathrm{~mm}$ specimen collected in Cabo Frio Island, Rio de Janeiro, Brazil, constituting the first record of the genus for the Atlantic Ocean. The species was described based on morphology, anatomy of internal organs and aspects of the radula. Subsequently, Ortea (2016) described a second species of this genus for the western Atlantic (C.madibenthos) from a $50 \mathrm{~mm}$ specimen found on the island of Martinique, Lesser Antilles. It was identified based on morphological aspects, reproductive structures and characteristics of the radula. 
para el Atlántico occidental (C. madibenthos) a partir de un ejemplar de $50 \mathrm{~mm}$ encontrado en la isla de Martinica, Antillas Menores. La identificación se realizó con base en aspectos morfológicos, estructuras reproductivas y características de la rádula.

Hasta el momento no se cuenta con ningún registro del género Carminodoris para el Pacífico o el Caribe colombiano. El presente trabajo es el primer registro del género para el Caribe colombiano y el tercero para el océano Atlántico. Por esta razón, se realiza la descripción del primer ejemplar del género Carminodoris recolectado en la isla San Martín de Pajarales, islas del Rosario, Caribe colombiano.

\section{MATERIALES Y MÉTODOS}

El molusco fue encontrado vivo dentro de un tanque de reproducción de peces marinos (de capacidad máxima de agua $100 \mathrm{~m}^{3}$ y profundidad $2,5 \mathrm{~m}$ ) en el oceanario de las islas del Rosario, el 31 de enero de 2018, durante labores de limpieza. Los tanques cuentan con varias tomas directas de agua del área adyacente al oceanario, convirtiéndose en un refugio para varios organismos como peces, moluscos y crustáceos.

El ejemplar recolectado vivo fue introducido en un acuario marino en el laboratorio del CEINER (Centro de Investigación, Educación y Recreación, San Martín de Pajarales, islas del Rosario) con el fin de facilitar la descripción macroscópica y posterior identificación, así como el registro fotográfico del mismo. Posteriormente el ejemplar fue preservado en etanol al 70\% para realizar la disección y análisis de la anatomía interna. Las observaciones de estructuras macroscópicas y microscópicas (rinóforos, rádula, plumón branquial, órganos internos, entre otros) se realizaron con ayuda de un estereoscopio (Carl Zeiss. Serial 2004010114) y un microscopio (Carl Zeiss. Serial 3108002222). Las fotografías fueron tomadas con un Iphone 5s.

\section{RESULTADOS}

Orden: Nudibranchia

Familia: Discodorididae Bergh, 1891

Género: Carminodoris Bergh, 1889 Carminodoris sp.

Material examinado: Un ejemplar recolectado vivo en un tanque de reproducción de peces marinos en el Oceanario,
So far there are no records of the genus Carminodoris for the Pacific or the Colombian Caribbean. This paper is the first record of the genus for the Colombian Caribbean and the third for the Atlantic Ocean. As such, we describe the first specimen of the genus Carminodoris collected on Isla San Martín de Pajarales, Islas del Rosario, Cartagena, Colombia.

\section{MATERIALS AND METHODS}

The mollusk was found alive inside a marine fish-breeding tank (maximum water capacity $100 \mathrm{~m}^{3}$ and depth $2.5 \mathrm{~m}$ ) in the oceanarium at Islas del Rosario, on January 31, 2018, during cleanup work. The tanks have several direct water intakes from the area adjacent to the oceanarium, providing refuge for various organisms such as fish, mollusks and crustaceans.

The specimen collected alive was introduced into a marine aquarium in the CEINER (Centro de Investigación, Educación y Recreación, San Martín de Pajarales, Islas del Rosario) laboratory for macroscopic description, subsequent identification, and photographic record. Subsequently, the specimen was preserved in $70 \%$ ethanol for dissection and internal anatomy analysis. The macroscopic and microscopic structures (rhinophores, radula, branchial plume, internal organs, among others) were observed using a stereoscope (Carl Zeiss. Serial 2004010114) and a microscope (Carl Zeiss. Serial 3108002222). The photographs were taken using an Iphone $5 \mathrm{~s}$.

\section{RESULTS}

Order: Nudibranchia

Family: Discodorididae Bergh, 1891

Genus: Carminodoris Bergh, 1889

Carminodoris sp.

Examined material: A specimen collected alive in a marine fishbreeding tank in the oceanarium at Isla San Martín de Pajarales, Islas del Rosario, Parque Nacional Natural Corales del Rosario y San Bernardo, Cartagena, Colombia. Collected by C. Zárate, on January 31,2018 . The live specimen recorded a length of $74 \mathrm{~mm}$ and a maximum width of $58 \mathrm{~mm}$ (Figure $1 \mathrm{~A}$ ). Once preserved, the mollusk contracted and its dimensions changed to $57 \mathrm{~mm}$ long and $42 \mathrm{~mm}$ wide (Figure $2 \mathrm{~A}-\mathrm{B}$ ).

Description: External morphology (Figure 1): The specimen's body is oval and flat, the back of the mantle is 
isla San Martín de Pajarales, islas del Rosario, Parque Nacional Natural Corales del Rosario y San Bernardo, Cartagena, Colombia. Recolectado por C. Zárate, 31 enero 2018. El ejemplar vivo registró una longitud de $74 \mathrm{~mm}$ y un ancho máximo de $58 \mathrm{~mm}$ (Figura $1 \mathrm{~A}$ ). Una vez preservado, el molusco se contrajo y sus dimensiones cambiaron a 57 $\mathrm{mm}$ de largo y $42 \mathrm{~mm}$ de ancho (Figura $2 \mathrm{~A} \mathrm{y} \mathrm{B}$ ).

Descripción: Morfología externa (Figura 1): Cuerpo del ejemplar ovalado y plano, dorso del manto color cafébronce hacia la parte central; parte anterior del mismo con coloración café oscura y café-bronce claro hacia los bordes. El manto presenta grandes manchas oscuras cerca al borde y en el centro, sin un patrón aparente (Figura 1 A-C). Todo el notum del ejemplar, salvo el área inmediatamente cercana a los rinóforos está cubierto por tubérculos más o menos redondeados, de tamaño variable, siendo mayores aquellos en la porción dorsal central (Figura 1A). A lo largo del borde del manto, los tubérculos disminuyen y se unen de manera compacta. La mayoría de tubérculos presenta un anillo blanco en la base, seguido de una aureola intermedia de color café claro, terminando en una punta café oscura al final de cada uno (Figura 1J). El plumón branquial se divide en seis hojas branquiales tripinadas plumosas de color café oscuro. La parte anterior del plumón y la parte posterior plumosa son de color café claro (Figuras 1 G-I y J1).

La vaina rinofórica (Figuras 1D2 y 1F1), así como la vaina branquial, es baja e irregular, con pequeños tubérculos redondeados a excepción de la parte interna. Rinóforos gruesos y altos con una base marrón y presentan una porción lamelar marrón clara, con una serie de laminillas apretadas y delgadas (aproximadamente 30) (Figura 1D-F y 1J3) y un mucrón terminal de coloración blanca (Figura 1D1).

Ventralmente el hiponoto posee una coloración café clara, ornamentado por pequeños puntos negros $(<2 \mathrm{~mm})$, que le dan una apariencia moteada (Figura 1 B). El borde ventral del manto también conserva grandes manchas negras al igual que el dorso, sin un patrón aparente (Figura $1 \mathrm{~B}$ y C). La base del pie es de color amarillo-marrón, bilabiado cerca del borde anterior (Figura 1 B, C y G2). En la cabeza se observan dos tentáculos digitiformes (Figura $1 \mathrm{G1}$ ). El pie del animal es grande, con una longitud cercana a tres cuartas de la longitud del manto, con múltiples estriaciones, sin ningún orden aparente (Figura 1 C). Su forma sigue el contorno ovalado del organismo. El ejemplar conservado en etanol a 70\% adquirió un color amarillo-pardo uniforme, dorsal y ventralmente (Figura 2A). El pie se contrajo siguiendo la forma de las estriaciones (Figura $2 \mathrm{~B}$ ). brown-bronze towards the central part; the anterior part of the mantle is dark brown and light brown-bronze towards the edges. The mantle has large dark spots near the edge and in the center, without an apparent pattern (Figure 1 A-C). The entire notum of the specimen, except for the area immediately around the rhinophores, is covered by more or less rounded tubercles of variable size, with those in the central dorsal portion being larger (Figure 1A). Along the edge of the mantle, the tubercles diminish and join in a compact fashion. Most tubercles have a white ring at the base, followed by an intermediate light brown aureole, ending in a dark brown tip at the end of each (Figure $1 \mathrm{~J}$ ). The branchial plume is divided into six dark brown, feathery tripinnate gill leaves. The front and back of the plume are light brown (Figures 1 G4, H, I y J1).

The rhinophore sheath (Figures 1D2 and 1F1) and the gill sheath are low and irregular, with small rounded tubercles except for the inner part. Thick, tall rhinophores with a brown base and a light brown lamellar portion, with a series of tight, thin gills (approximately 30) (Figure 1D-F and 1J3) and a white terminal mucron (Figure 1D1).

On the abdomen, the hyponotum is light brown with small black dots $(<2 \mathrm{~mm})$, which give it a mottled appearance (Figure 1B). The ventral edge of the mantle also bears large black spots as does the back, without an apparent pattern (Figure $1 \mathrm{~B}-\mathrm{C}$ ). The base of the foot is yellow-brown, bilabiated near the front edge (Figure $1 \mathrm{~B}, \mathrm{C}$ and G2). Two digitiform tentacles are observed on the head (Figure 1G1). The foot of the animal is large, close to three quarters of the length of the mantle, with multiple striations, in no apparent order (Figure 1C). Its shape follows the oval contour of the organism. The specimen conserved in $70 \%$ ethanol acquired a uniform yellow-brown color, dorsally and ventrally (Figure 2A). The foot contracted following the shape of the striations (Figure 2B).

Internal morphology: The mouth is at the top of the ventral view, located above the salivary gland and nerve ganglion (Figure 3A). Bulging digestive gland. Large amount of yellow gastrointestinal muscle (Figure 3A3). The organism's jaw is rounded and irregular. The radula was found to be oppressed and irregular in a circular fashion (Figure), with which it was possible to generate an approximate radular formula: $>40 \times 20-30.0 .20-30$. All teeth are smooth and hook shaped (Figure 3E). The size of the teeth increases progressively along each row. The first third of teeth are hook-shaped, long and thin towards the base (Figure 3D3 and 3E3). The second third has a long, smooth 


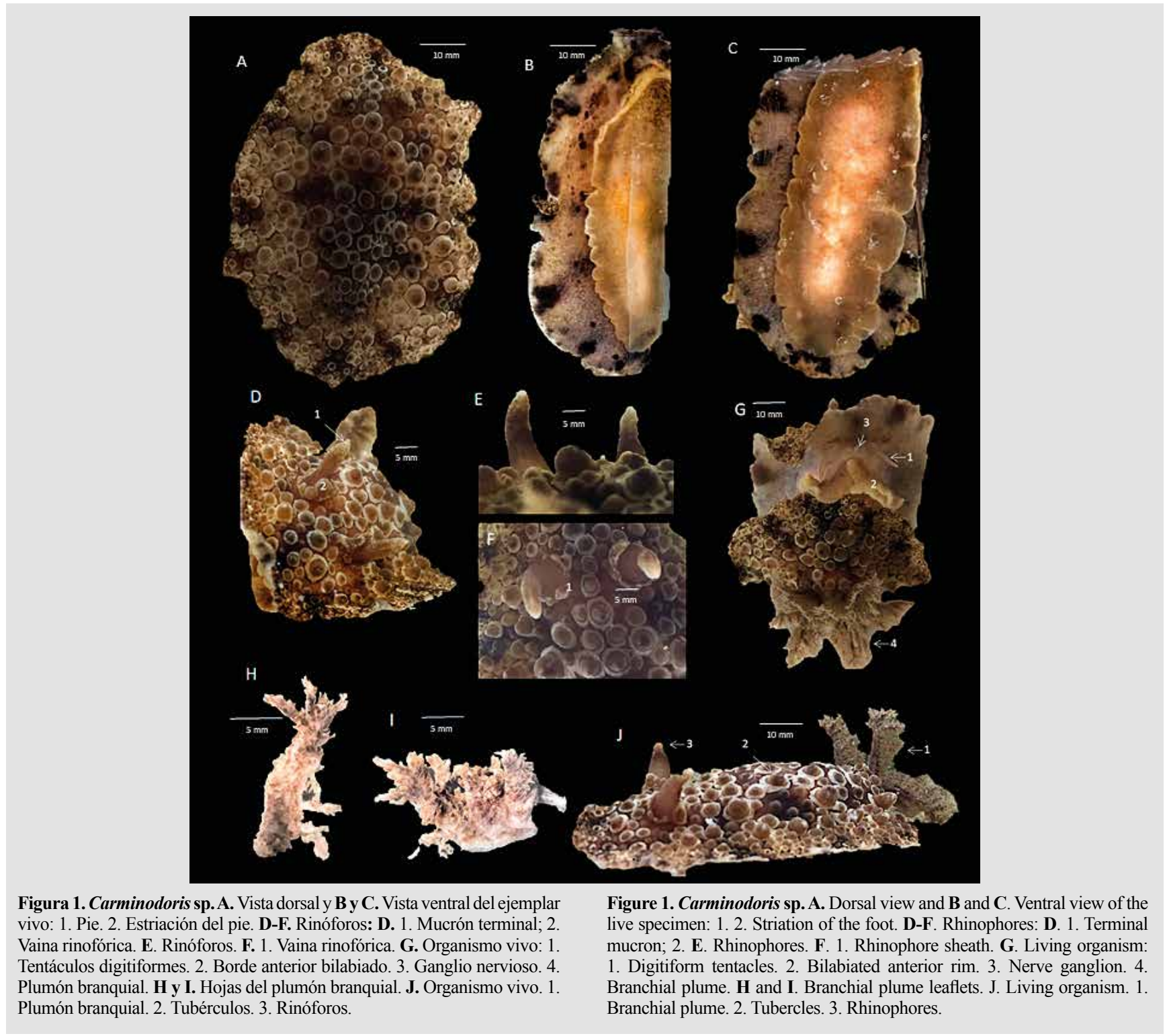

Morfología interna: Boca en la parte superior de la vista ventral, ubicada por encima de la glándula salival y el ganglio nervioso (Figura 3A). Glándula digestiva abultada. Gran cantidad de músculo gastrointestinal de color amarillo (Figura 3A). La mandíbula del organismo es redondeada y de manera irregular. La rádula se encontró oprimida e irregular de manera circular (Figura 3B-F), con la cual se logró generar un aproximado de la fórmula radular: $>40 \times 20-30 \cdot 0 \cdot 20-30$. Todos los dientes tienen forma lisa y de gancho (Figura 3E). El tamaño de los dientes aumenta de forma progresiva a lo largo de cada hilera. El primer tercio de dientes poseen forma de gancho, larga y delgada hacia la base (Figura 3D y 3E). hook and a thick base (Figure 3C, 3F, 3E1 and 3E2). In the third third they decrease in size regularly and progressively with a short, smooth hook and a thick-robust base (Figure 3D4 and 3E4). The genital openings are located on the right anterior flank, near the head.

\section{DISCUSSION}

According to Valdés (2002), the genus Carminodoris has several key characteristics: the dorsal portion of the mantle is covered by large simple and rounded tubercles; its head has two cone-shaped oral tentacles; a bifurcated, grooved and notched forefoot rim; labial armor with mandibular elements; radula composed 
El segundo tercio posee un gancho largo y liso y una base gruesa (Figura 3C, 3F, 3E1 y 3E2). En el tercer tercio disminuyen de tamaño de manera regular y progresiva con un gancho corto, liso y una base gruesa-robusta (Figura 3D4 y 3E4). Las aberturas genitales se sitúan en el flanco derecho anterior, cerca de la cabeza. of bone-cultured simple regular teeth. The specimen studied differs from the other species described in the genus because of its size. All the species described have been recorded as being in a length range of 20 to $54 \mathrm{~mm}$ (Table 1), while the specimen collected had a total length of $74 \mathrm{~mm}$. The specimen described here is phenotypically

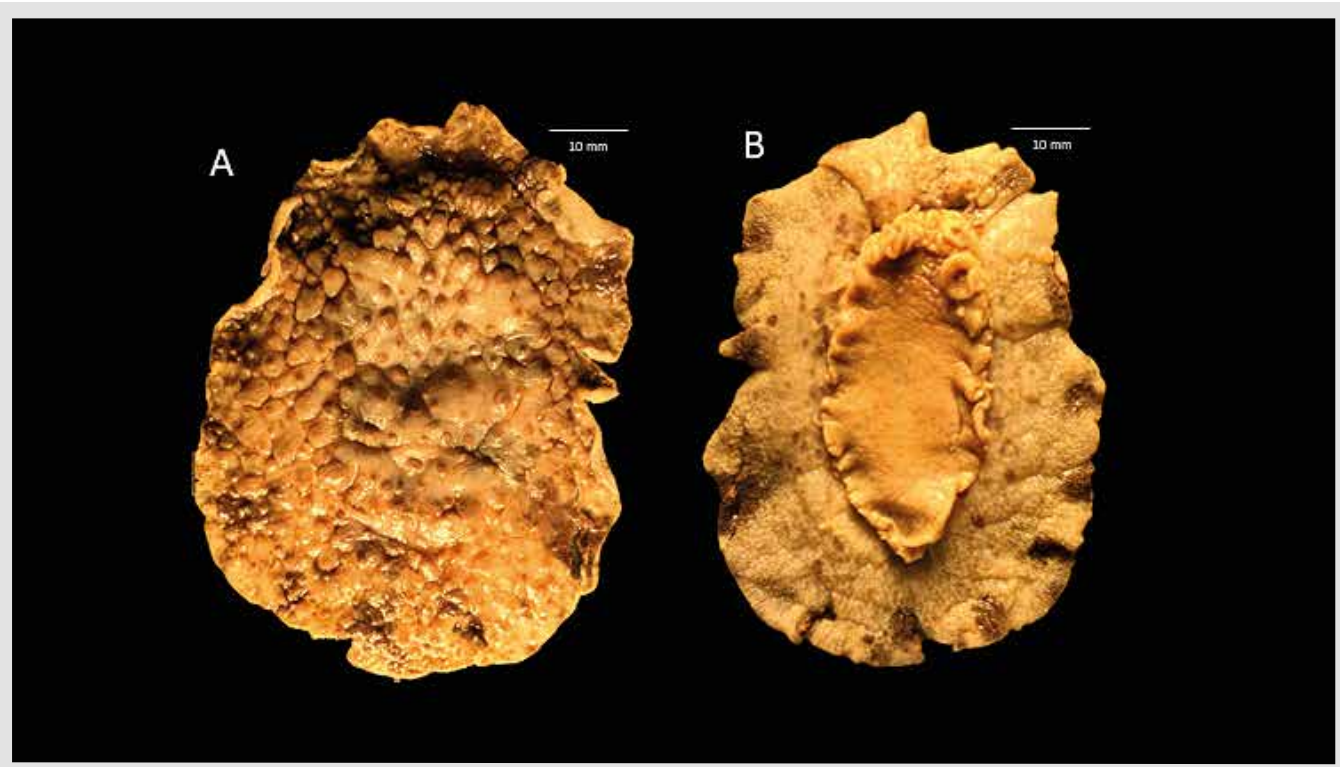

Figura 2. Carminodoris sp. material preservado en etanol al 70\%. A. Vista dorsal B. Vista ventral.

Figure 2. Carminodoris sp. material preserved in ethanol at $70 \%$. A. Dorsal view B. Ventral view.

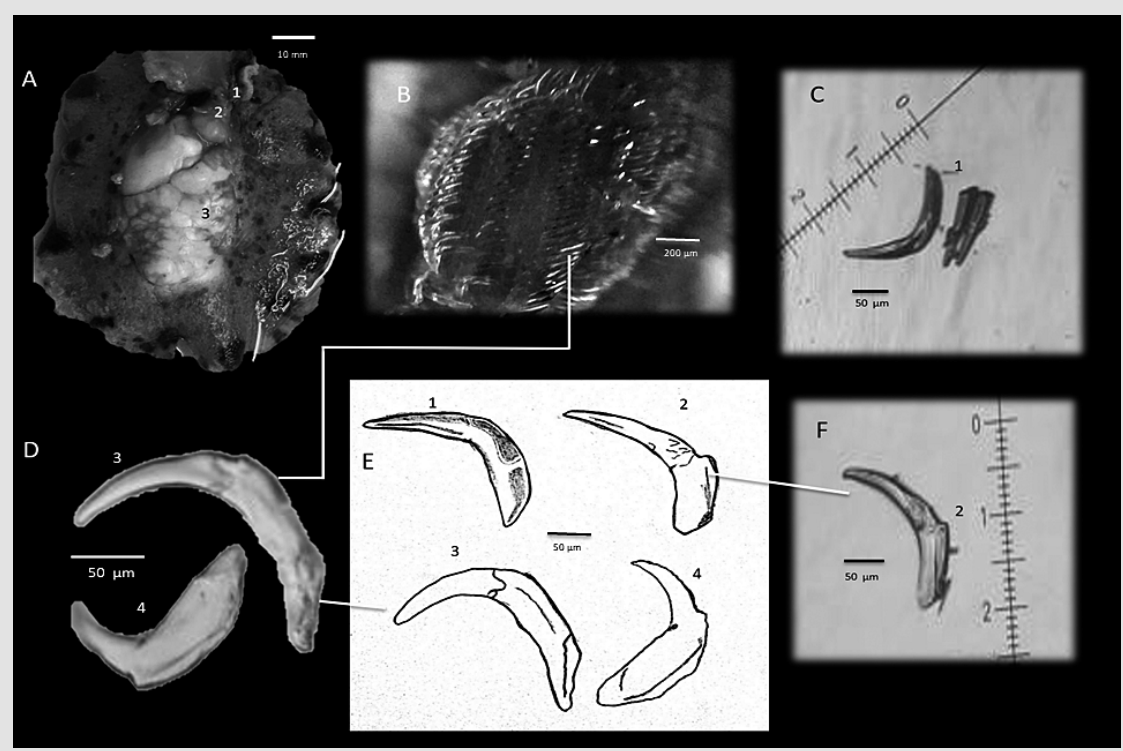

Figura 3. Detalles de disección del ejemplar estudiado. A. 1. Glándula salival. 2. Ganglio nervioso. 3. Glándula digestiva. B. Rádula. C y F. Dientes del segundo tercio de la rádula. D. Dientes del primer (3) y tercer (4) tercio de la rádula. E. Dientes de la rádula.
Figure 3. Dissection details of the specimen studied. Salivary gland. Nerve ganglion. 3. Digestive gland. B. Radula. C and F. Teeth of the second third of the radula. D. Teeth of the first (3) and third (4) third of the radula. E. Teeth of the radula. 


\section{DISCUSIÓN}

Según Valdés (2002), el género Carminodoris posee varios caracteres claves como son la porción dorsal del manto cubierta por tubérculos grandes simples y redondeados, cabeza con dos tentáculos orales en forma de cono, borde anterior del pie bifurcado, acanalado y con muescas; armadura labial con elementos mandibulares; rádula compuesta por dientes simples, con dentículos regulares y de color hueso. El ejemplar estudiado difiere de las demás especies descritas del género por su talla. Todas las especies descritas se han registrado en el ámbito de longitud de 20 a $54 \mathrm{~mm}$ (Tabla 1), mientras que el espécimen recolectado presentó una longitud total de $74 \mathrm{~mm}$.

El espécimen que aquí se describe es fenotípicamente similar a $C$. hansrosaorum (Domínguez et al., 2006; Alvim y Pimenta, 2013) y C. madibenthos (Ortea, 2016) del océano Atlántico, así como a $C$. nodulosa (Fahey y Gosliner, 2003), C. bramale (Fahey y Gosliner, 2003) y C. grandiflora (Fahey y Gosliner, 2003) del océano Pacífico (Tabla 1). El manto de la mayoría de tales especies tiene una coloración café y posee una serie de tubérculos rodeados por un aro blanco en la base. Sin embargo, el ejemplar que aquí se describe posee un patrón de coloración diferente hacia la parte anterior-central del dorso, donde toma una coloración café-negra oscura y un café-bronce claro hacia los bordes. Adicionalmente, posee manchas grandes hacia el borde del manto, diferenciándose de la mayoría de tales especies, ya que, si las tienen, se encuentran de manera tenue o como en el caso de $C$. grandiflora, se ubican en la parte central del manto. De igual modo, el ejemplar muestra un patrón diferencial marcado en la parte del hiponoto frente a las otras especies, ya que al compararlo con $C$. hansrosaorum es similar en el esquema moteado hacia la zona central, pero difiere por las grandes manchas negras marcadas en el borde ventral. Del mismo modo, $C$. madibenthos y $C$. bramale difieren en esta parte, ya que éstas solo retienen algunas manchas pálidas, y la fracción ventral central no es moteada (Fahey y Gosliner, 2003; Ortea, 2016). En otros casos, como el de $C$. nodulosa, la porción ventral no conserva ningún pigmento (Domínguez et al., 2006).

Los rinóforos de Carminodoris sp. son distintos a los de las otras especies ya descritas por su coloración. Los rinóforos de C. nodulosa y $C$. madibenthos poseen 32 y 30 laminillas respectivamente (Tabla 1), tal y como se encontró en el espécimen estudiado. Sin embargo, los similar to C. hansrosaorum (Domínguez et al., 2006; Alvim and Pimenta, 2013) and C. madibenthos (Ortea, 2016) from the Atlantic Ocean, as well as $C$. nodulosa (Fahey and Gosliner, 2003), C. bramale (Fahey and Gosliner, 2003) and C. grandiflora (Fahey and Gosliner, 2003) from the Pacific Ocean (Table 1). The mantle of most such species is brown and has a series of tubercles surrounded by a white ring at the base. However, the specimen described here has a different coloration pattern towards the anterior-central part of the dorsum, where it takes on a dark brown-black coloration and a light brownbronze towards the edges. It has large spots towards the edge of the mantle, differentiating it from most such species, as in the others, when they are present; they tend to be tenuous or, as in the case of $C$. grandiflora, located in the center of the mantle. Similarly, the specimen shows a marked differential pattern from the other species in the hyponotum. When compared with $C$. hansrosaorum, it is similar in the mottled scheme towards the central zone, but differs by the large black spots marked on the ventral edge. Similarly, $C$. madibenthos and $C$. bramale differ in this part, as they only have some pale spots, and the central ventral fraction is not mottled (Ortea, 2016; Fahey and Gosliner, 2003). In other cases such as $C$. nodulosa, the ventral portion has no pigment (Domínguez et al., 2006).

The rhinophores of Carminodoris sp. are different from those of the other species already described for their coloring. The rhinophores of $C$. nodulosa and $C$. madibenthos have 32 and 30 gills, respectively (Table 1), as found in the specimen studied. However, the rhinophores of $C$. madibenthos have a violet grey coloration and do not have a terminal mucron (Ortea, 2016). The branchial plume of the specimen studied differs only from that of $C$. madibenthos, which is tetrapinnate (Ortea, 2016).

The foot of the specimen is very different to the specimens of Carminodoris registered for the Atlantic, because it is quite wide and with multiple striations. The foot of $C$. madibenthos is moderately wide, with few striations, while that of $C$. hansrosaorum is narrow.

Internally, the specimen under study is close in its radular formula to $C$. armata $(45 \times 50-60.0 .50-60$; Pacific species) and $C$. grandiflora (26-40 x 40-116.0.40-116; Pacific species, Madagascar) (Table 1). This feature is key in differentiating it from the other species in both genera, because the number of rows of teeth varies between 24 and 38 and the approximate number of teeth for this specimen is greater than 40 . Similarly, C. armata, $C$. hansrosaorum, $C$. 
rinóforos de $C$. madibenthos tienen una coloración gris violáceo y no poseen un mucrón terminal sobre los mismos (Ortea, 2016). El plumón branquial del espécimen estudiado difiere únicamente con aquel de $C$. madibenthos, el cual es tetrapinado (Ortea, 2016).

El pie del espécimen muestra una gran diferencia frente a los ejemplares de Carminodoris registrados para el Atlántico, debido a que es bastante ancho y con múltiples estriaciones. El pie de $C$. madibenthos es moderadamente ancho, con pocas estriaciones, mientras que el de $C$. hansrosaorum es estrecho. bramale and $C$. madibenthos have teeth with denticles and the specimen under study has smooth and hooked teeth. This is a distinctive feature when compared to $C$. hansrosaorum (Ortea, 2016), which is shared with $C$. madibenthos, differing in the second and third third of the teeth, which have a smooth hook and a thick-robust base (distinctive feature when compared to $C$. madibenthos).

Species such as $C$.grandiflora (Fahey and Gosliner, 2003), C. bifurcata (Fahey and Gosliner, 2003), C. nodulosa (Fahey and Gosliner, 2003), C. bramale (Fahey and Gosliner, 2003), C. bifurcata (Fahey and Gosliner, 2003).

Tabla 1. Caracteres diagnósticos en especies de nudibranquios del género Carminodoris (tomada y modificada de Domínguez et al., 2006)

Table 1. Diagnostic characters in nudibranch species of the genus Carminodoris (taken and modified from Domínguez et al., 2006)

\begin{tabular}{|c|c|c|c|c|c|}
\hline & Carminodoris sp. & C. hansrosaorum & C. bramale & C. nodulosa & C. madibenthos \\
\hline $\begin{array}{l}\text { Referencias } \\
\text { References }\end{array}$ & $\begin{array}{l}\text { Zárate } \text { et al. (presente } \\
\text { estudio) }\end{array}$ & $\begin{array}{l}\text { Domínguez et al. } \\
\text { (2006) }\end{array}$ & $\begin{array}{l}\text { Fahey y Gosliner } \\
\text { (2003) }\end{array}$ & $\begin{array}{l}\text { Fahey y Gosliner } \\
\text { (2003) }\end{array}$ & Ortea (2016) \\
\hline Distribución & Cartagena, Colombia & Brasil & $\begin{array}{c}\text { Costa pacífica de Costa } \\
\text { Rica }\end{array}$ & $\begin{array}{c}\text { Australia y Nueva } \\
\text { Zelanda }\end{array}$ & $\begin{array}{l}\text { Martinica, } \\
\text { Antillas } \\
\text { Menores }\end{array}$ \\
\hline Distribution & & Brazil & $\begin{array}{l}\text { Pacific coast of Costa } \\
\text { Rica }\end{array}$ & $\begin{array}{c}\text { Australia and New } \\
\text { Zealand }\end{array}$ & \\
\hline Coloración dorsal & $\begin{array}{l}\text { Dorso del manto color } \\
\text { café-bronce, hacia la } \\
\text { parte central. Parte } \\
\text { anterior del dorso con } \\
\text { coloración café oscura, } \\
\text { y hacia los bordes café } \\
\text { bronce claro y grandes } \\
\text { manchas oscuras de } \\
\text { color negro cerca al } \\
\text { borde del manto y en } \\
\text { el centro del mismo, } \\
\text { ningún patrón aparente }\end{array}$ & $\begin{array}{c}\text { Naranja-café. Dorso } \\
\text { naranja blanquecino } \\
\text { hacia el borde del } \\
\text { manto }\end{array}$ & Café o bronce & $\begin{array}{l}\text { Gris a amarillo y } \\
\text { marrones rojizos, con } \\
\text { tonos moteados de } \\
\text { tonos más oscuros, } \\
\text { color más claro en el } \\
\text { dorso central }\end{array}$ & $\begin{array}{c}\text { Manto de } \\
\text { color gris violáceo zona } \\
\text { central ocre anaranjado. } \\
\text { Manchas grandes } \\
\text { oscuras, dispuestas en } \\
\text { la superficie sin orden } \\
\text { aparente }\end{array}$ \\
\hline Dorsal Coloration & $\begin{array}{l}\text { Brown-bronze mantle } \\
\text { back, towards the } \\
\text { central part. Anterior } \\
\text { part of the back with } \\
\text { dark brown coloration, } \\
\text { and towards the edges } \\
\text { light brown bronze and } \\
\text { large dark black spots } \\
\text { near the edge of the } \\
\text { mantle and no apparent } \\
\text { pattern in the center }\end{array}$ & $\begin{array}{l}\text { Orange-brown. Orange } \\
\text { dorsum whitish towards } \\
\text { the edge of the mantle }\end{array}$ & Brown or bronze & $\begin{array}{l}\text { Gray to yellow and } \\
\text { reddish browns, with } \\
\text { mottled darker tones, } \\
\text { lighter on the central } \\
\text { dorsum }\end{array}$ & $\begin{array}{l}\text { Grey violet mantle, } \\
\text { ocher orange central } \\
\text { area. Large dark spots, } \\
\text { arranged on the surface } \\
\text { in no apparent order }\end{array}$ \\
\hline Branquia & Tripinada & Tripinada & Tripinada & Tripinada & Tetrapinada \\
\hline Gill & Tripinnate & Tripinnate & Tripinnate & Tripinnate & Tetrapinnate \\
\hline Tubérculos & $\begin{array}{l}\text { Cada tubérculo presenta } \\
\text { un anillo blanco en la } \\
\text { base, seguido de una } \\
\text { aureola intermedia café } \\
\text { claro, terminando en } \\
\text { una punta café oscura }\end{array}$ & $\begin{array}{l}\text { Naranja-café, con un } \\
\text { aro blanco en la base }\end{array}$ & $\begin{array}{l}\text { Cafés con un aro } \\
\text { blanco en la base }\end{array}$ & $\begin{array}{l}\text { Gris a amarillo y rojo- } \\
\text { café. Moteado, con un } \\
\text { color más distintivo en } \\
\text { el dorso }\end{array}$ & $\begin{array}{l}\text { Violetas tornándose a } \\
\text { anaranjado con } \\
\text { un anillo blanco } \\
\text { rodeando la base }\end{array}$ \\
\hline
\end{tabular}




\begin{tabular}{|c|c|c|c|c|c|}
\hline & Carminodoris sp. & C. hansrosaorum & C. bramale & C. nodulosa & C. madibenthos \\
\hline Tubercles & $\begin{array}{l}\text { Each tubercle has } \\
\text { a white ring at the } \\
\text { base, followed by } \\
\text { an intermediate light } \\
\text { brown aureole, ending } \\
\text { in a dark brown tip }\end{array}$ & $\begin{array}{l}\text { Orange-brown, with a } \\
\text { white ring at the base }\end{array}$ & $\begin{array}{l}\text { Brown with a white } \\
\text { ring at the base }\end{array}$ & $\begin{array}{l}\text { Grey to yellow and red- } \\
\text { brown. Mottled, with a } \\
\text { more distinctive color } \\
\text { on the back }\end{array}$ & $\begin{array}{l}\text { Violet turning orange } \\
\text { with a white ring } \\
\text { surrounding the base }\end{array}$ \\
\hline Rinóforos & $\begin{array}{l}\text { Rinóforos gruesos } \\
\text { y altos con un tallo } \\
\text { marrón medio. Porción } \\
\text { lamelar marrón } \\
\text { claro, que termina } \\
\text { en una punta blanca. } \\
\text { Laminillas apretadas } \\
\text { y delgadas (aprox. } 30 \\
\text { laminillas). Mucrón } \\
\text { terminal de coloración } \\
\text { blanca }\end{array}$ & $\begin{array}{l}\text { Naranja con una } \\
\text { terminación crema, con } \\
\text { aprox. } 15 \text { laminillas }\end{array}$ & $\begin{array}{c}\text { Café con una } \\
\text { terminación blanca (10- } \\
13 \text { laminillas) }\end{array}$ & $\begin{array}{l}\text { Color bronce. Café } \\
\text { oscuro en la porción } \\
\text { lamela, con aprox. } 32 \\
\text { laminillas terminadas } \\
\text { en coloración } \\
\text { blanquecina }\end{array}$ & $\begin{array}{l}\text { Coloración violácea } \\
\text { (aprox. } 30 \text { laminillas } \\
\text { apretadas y delgadas) }\end{array}$ \\
\hline Rhinophores & $\begin{array}{l}\text { Thick, tall rhinophores } \\
\text { with a medium brown } \\
\text { stem. Light brown } \\
\text { lamellar portion, ending } \\
\text { in a white tip. Tight and } \\
\text { thin gills (approx. } 30 \\
\text { gills). White terminal } \\
\text { mucron }\end{array}$ & $\begin{array}{l}\text { Orange with a cream } \\
\text { edge, with approx. } 15 \\
\text { gills }\end{array}$ & $\begin{array}{l}\text { Brown with a white } \\
\text { edge (10-13 gills) }\end{array}$ & $\begin{array}{l}\text { Bronze in color. Dark } \\
\text { brown in the lamella } \\
\text { portion, with approx. } \\
32 \text { gills finished in } \\
\text { whitish coloration }\end{array}$ & $\begin{array}{l}\text { Purplish coloration } \\
\text { (approx. } 30 \text { tight and } \\
\text { thin gills) }\end{array}$ \\
\hline Hiponoto & $\begin{array}{l}\text { Moteado con manchas } \\
\text { pequeñas }(<2 \mathrm{~mm}) \text {. } \\
\text { Manchas negras } \\
\text { grandes hacia los } \\
\text { bordes del manto }\end{array}$ & $\begin{array}{c}\text { Punteado a ambos lados } \\
\text { del pie, con coloración } \\
\text { naranja-café }\end{array}$ & $\begin{array}{l}\text { Algunas manchas } \\
\text { oscuras se retienen en } \\
\text { la parte ventral }\end{array}$ & $\begin{array}{l}\text { Lado ventral del } \\
\text { espécimen no conserva } \\
\text { ningún pigmento }\end{array}$ & $\begin{array}{l}\text { Coloración grisácea, } \\
\text { con entramado de } \\
\text { espículas blanquecinas }\end{array}$ \\
\hline Hyponotum & $\begin{array}{l}\text { Speckled with small } \\
\text { spots }(<2 \mathrm{~mm}) \text {. Large } \\
\text { black spots towards the } \\
\text { edges of the coat }\end{array}$ & $\begin{array}{l}\text { Dotted on both sides of } \\
\text { the foot, with orange- } \\
\text { brown coloration }\end{array}$ & $\begin{array}{l}\text { Some dark spots on the } \\
\text { abdomen }\end{array}$ & $\begin{array}{l}\text { No pigment on the } \\
\text { specimen's abdomen }\end{array}$ & $\begin{array}{l}\text { Grayish coloration, } \\
\text { with a framework of } \\
\text { whitish spicules }\end{array}$ \\
\hline Rádula & $\begin{array}{c}\text { Fórmula radular: } \\
>40 \text { x 20-30.0.20-30 } \\
\text { Dientes en forma de } \\
\text { gancho simples y } \\
\text { lisos, sin estriaciones. } \\
\text { Tamaño variable }\end{array}$ & $\begin{array}{c}\text { Fórmula radular: } \\
24 \text { x 31.0.31 } \\
\text { Dientes con dentículos }\end{array}$ & $\begin{array}{c}\text { Fórmula radular: } \\
28 \times 38.0 .38 \\
\text { Dientes suaves con } \\
\text { dentículos }\end{array}$ & $\begin{array}{c}\text { Fórmula radular: } \\
25 \text { x } 53.0 .53 \\
\text { Dientes cortos y } \\
\text { denticulados (laterales). } \\
\text { Algunos dientes del } \\
\text { medio son suaves }\end{array}$ & $\begin{array}{c}\text { Fórmula } \\
\text { radular: } \\
35 \times 48.0 .48 \\
35 \times 59.0 .59 \\
\text { Todos los } \\
\text { dientes en forma de } \\
\text { forma de } \\
\text { gancho y lisos }\end{array}$ \\
\hline Radula & $\begin{array}{c}\text { Radular formula: } \\
>40 \times 20-30.0 .20- \\
30 \text { Simple, smooth } \\
\text { hooked teeth, without } \\
\text { striations. Variable in } \\
\text { size }\end{array}$ & $\begin{array}{l}\text { Radular formula: } \\
24 \times 31.0 .31 \\
\text { teeth with denticles }\end{array}$ & $\begin{array}{l}\text { Radular formula: } \\
28 \times 38.0 .38 \\
\text { smooth teeth with } \\
\text { denticles }\end{array}$ & $\begin{array}{c}\text { Radular formula: } \\
25 \times 53.0 .53 \\
\text { Short, denticulated } \\
\text { (lateral) teeth. Some } \\
\text { middle teeth are smooth }\end{array}$ & $\begin{array}{l}\text { Radular formula: } \\
\quad 35 \times 48.0 .48 \\
35 \times 59.0 .59 \\
\text { All teeth are hook- } \\
\text { shaped and smooth }\end{array}$ \\
\hline Mandíbula & Redondeada e irregular & Redondeada e irregular & Bordes irregulares & Irregular & Irregular \\
\hline Jaw & Rounded and irregular & Rounded and irregular & Irregular edges & Irregular & Irregular \\
\hline Pie & $\begin{array}{l}\text { Pie grande, ocupa } 3 / 4 \\
\text { el tamaño del manto. } \\
\text { Múltiples estriaciones } \\
\text { sin ningún orden } \\
\text { aparente }\end{array}$ & $\begin{array}{l}\text { Estrecho y alargado, } \\
\text { con muesca }\end{array}$ & Pie con muesca & $\begin{array}{c}\text { Pie con muesca } \\
\text { redondeada en el lado } \\
\text { anterior }\end{array}$ & $\begin{array}{c}\text { Base del pie } \\
\text { más corta que } \\
\text { el manto y } \\
\text { sigue el contorno del } \\
\text { animal }\end{array}$ \\
\hline Foot & $\begin{array}{c}\text { Large foot, occupies } 3 / 4 \\
\text { the size of the mantle. } \\
\text { Multiple striations } \\
\text { without any apparent } \\
\text { order } \\
\end{array}$ & $\begin{array}{c}\text { Narrow, elongated and } \\
\text { notched }\end{array}$ & Notched foot & $\begin{array}{l}\text { Foot with rounded } \\
\text { notch on the front }\end{array}$ & $\begin{array}{l}\text { Base of the foot shorter } \\
\text { than the mantle and } \\
\text { follows the contour of } \\
\text { the animal }\end{array}$ \\
\hline
\end{tabular}


Internamente, el espécimen en estudio se aproxima en su fórmula radular a $C$. armata (45 x 50-60.0.5060 ; especie del Pacífico) y C. grandiflora (26-40 x 40116.0.40-116; especie del Pacífico, Madagascar) (Tabla 1). Este carácter es clave para la diferenciación con las demás especies de ambos géneros, debido a que el número de hileras de dientes varía entre 24 y 38 y el número aproximado de dientes para este espécimen es mayor a 40. De la misma manera, $C$. armata, $C$. hansrosaorum, $C$. bramale y $C$. madibenthos presentan dientes con dentículos y el espécimen en estudio tiene dientes lisos y en forma de gancho, carácter distintivo frente a $C$. hansrosaorum (Ortea, 2016), lo cual es compartido con $C$. madibenthos, diferenciándose en el segundo y tercer tercio de dientes, que poseen un gancho liso y una base gruesa-robusta (carácter distintivo frente a $C$. madibenthos).

Especies como C. grandiflora (Fahey y Gosliner, 2003), C. bifurcata (Fahey y Gosliner, 2003), C. nodulosa (Fahey y Gosliner, 2003), C. bramale (Fahey y Gosliner, 2003), C. estrelyado (Gosliner and Behrens, 1998), $C$. flammea (Fahey y Gosliner, 2003) y C. armata (Baba, 1993) tienen una distribución que incluye los océanos Pacífico e Índico. Con relación a la distribución geográfica en el Atlántico, Carminodoris sp. es el primer registro del género para Colombia y el tercero para ese océano. Por tal motivo, se presume que podría tratarse de una nueva especie para el Caribe, siendo necesario un mayor número de ejemplares y estudios moleculares para corroborar su identidad.

\section{AGRADECIMIENTOS}

Los autores agradecen al Centro de Investigación, Educación y Recreación- CEINER y al Parque Nacional Natural Corales del Rosario y San Bernardo-PNNCRSB. A Rafael Vieira, Jaime Rojas, Robin de la Rosa, y Ángel Valdés (California State Polytechnic University) por sus comentarios y apreciación del espécimen en estudio.
C. estrelyado (Gosliner and Behrens, 1998), C. flammea (Fahey and Gosliner, 2003) and C. armata (Baba, 1993), are species whose distribution has been mentioned for the Pacific and Indian Oceans. Regarding the geographical distribution in the Atlantic, Carminodoris sp. is the first record of the genus for Colombia and the third for the Atlantic. This is why it is presumed that it could be a new species for the Caribbean; more specimens and molecular studies are needed to corroborate its identity.

\section{ACKNOWLEDGEMENT}

The authors thank the Centro de Investigación, Educación y Recreación- CEINER and the Parque Nacional Natural Corales del Rosario y San Bernardo-PNNCRSB. They also thank Rafael Vieira, Jaime Rojas, Robin de la Rosa, and Ángel Valdés (California State Polytechnic University) for their comments and assessment of the specimen under study. 


\section{BIBLIOGRAFÍA / LITERATURE CITED}

Alvim J. and A.D. Pimenta. 2013. Taxonomic review of the family Discodorididae (Mollusca: Gastropoda: Nudibranchia) from Brazil, with descriptions of two new species. Zootaxa, 3745(2): 152-198.

Ardila, N. E., D. Báez y Á. Valdés. 2007. Babosas y liebres de mar (Mollusca: Gastropoda: Opisthobranchia) de Colombia. Biota Col., 8(2): 185-197.

Cervera, J.L., G. Calado, C. Gavaia, M.A.E. Malaquias, J. Templado, M. Ballesteros, M. and C. Megina. 2004. An annotated and updated checklist of the opisthobranchs (Mollusca: Gastropoda) from Spain and Portugal (including islands and archipelagos). Bol. Inst. Esp. Oceanogr., 20(1-4): 1-122.

Dayrat, B. 2010. A monographic revision of basal discodorid sea slugs (Gastropoda, Opisthobranchia, Nudibranchia, Doridina). Proc. Calif. Acad. Sci. Series 4, suppl. I, 61: 1-403, 382.

Díaz, J., J. Pinzón, J. Garzón-Ferreira, L. Boulon, M. López, M. Cendales, F. Velandia, F. Zapata, G. Ospina, B. Vargas y S. Zea. 2000. Áreas coralinas de Colombia. Ser. Publ. Esp. Invemar, 5: 31-45.

Domínguez, M., F. García and J. Troncoso. 2006. A new species of Hoplodoris Bergh, 1880 (Gastropoda: Opisthobranchia: Nudibranchia) from the Atlantic Ocean. The Nautilus, 120(4): 150-155.

Fahey, S. and T. M. Gosliner. 2003. Mistaken identities: On the Discodorididae genera Hoplodoris Bergh, 1880 and Carminodoris Bergh, 1889 (Opisthobranchia, Nudibranchia). Proc. Calif. Acad. Sci., 54(10): 169-208.

Flores-Rodríguez, P., R. Flores-Garza, S. García-Ibáñez, A. Valdés-González, B.G. Martínez-Vásquez, Y. Mora-Marín y E. J. González-Sandoval. 2017. Riqueza, composición de la comunidad y similitud de las especies bentónicas de la subclase Opisthobranchia (Mollusca: Gastropoda) en cinco sitios del litoral de Acapulco, México. Rev. Biol. Mar. Oceanogr., 54(1): 67-80.

Gosliner, T. 1994. Gastropoda: Opisthobranchia. 253-355. In: Harrison, F. and A. Kohn. (Eds.). Microscopic anatomy of invertebrates. New York. 498 p.

Gosliner, T. M. and D. W. Behrens. 1998. Two new discodorid nudibranchs from the Western Pacific with a redescription of Doris luteola Kelaart, 1858. Proc. Calif. Acad. Sci. serie 4, 50(11): 279-293.

Miller, M. 1991. On the identity of the dorid nudibranch Homoiodoris novaezelandiae Bergh, 1904 (Gastropoda: Opisthobranchia). J. Nat. Hist., 25(2): $293-304$.

Ortea, J. 2016. Una segunda especie atlántica del género Hoplodoris Bergh, 1880 (Mollusca: Nudibranchia) colectada en Martinica, Antillas Menores. Rev. Acad. Canar. Cienc., 28: 201-208.

Valdés, A. 2002. A phylogenetic analysis and systematic revision of the cryptobranch dorids (Mollusca, Nudibranchia, Anthobranchia). Zool. J. Linnean Soc., 36: 535-636.

WoRMS Editorial Board, 2019. World register of marine species. Available from http://www.marinespecies.org at VLIZ. Accessed 2019-05-15. doi: $10.14284 / 170$. 